\title{
The Effect of Financial Literacy and Knowledge of Capital Market on Intention to Invest on Islamic Stock Exchange
}

\author{
Malkan Malkan ${ }^{1}$, Hilal Malarangan ${ }^{2}$, Nurdin Nurdin ${ }^{3}$ \\ ${ }^{1,2}$ Faculty of Islamic Economic and Business, Universitas Islam negeri Datokarama Palu, Indonesia \\ ${ }^{3}$ Postgraduate Studies Univesrsitas Islam Negeri Datokarama Palu, Indonesia
}

\begin{abstract}
This study aims to find out the effect of financial literacy and knowledge capital market on intention to invest in Islamic stock exchange. Our study employed a quantitative method using survey techniques. Samples of this study were ninety-four students randomly selected from two departments of Islamic economy and banking within the Faculty of Islamic Economics and Business of State University of Islamic Studies Datokarama Palu, Indonesia. Our study found that financial literacy variables and knowledge of the capital market have a positive and significant effect on the students' interest in the Islamic capital market. Financial literacy played a more dominant role compared to the knowledge on the capital market variable. Our study highlighted an important point is that attracting a new generation in the Islamic capital market requires more attention from government and education institutions to provide them with sufficient knowledge and literacy of capital market and financial. Future studies need to study a better way to provide the young generation with financial literacy and capital market knowledge.
\end{abstract}

KEYWORDS: Capital Market Knowledge, Financial Literacy, Islamic Stock Exchange, Islamic Economic

\section{INTRODUCTION}

In the current era of growing globalization, the capital market effectively encourages economic growth and national development (Osinubi \& Amaghionyeodiwe, 2003). The capital market has become an attractive investment destination for domestic and foreign investors. With the increasing number of investors in the capital market, it becomes a reference that people are increasingly aware of the importance of investing, significantly investing in the Islamic capital market (Wahyudi \& Sani, 2014).

Considering the population of Indonesia in 2020, which has a total of 273 million citizens, and as many as 2.5 million Indonesian citizens have become investors in the capital market, it is a potential for the development and progress of the Indonesian state (Wahyuni \& Astuti, 2021). Due to the higher interest of investors to invest in the capital market, the selling and buying activities in the capital market are increasing, indicating that the business activities of various companies are running well.

The Islamic capital market is simply a place or means of meeting demand and supply for traded sharia shares. It refers to the Indonesian government Law on the Capital Market Number 8 of 1995, which defines the capital market as "activities related to public offerings and securities views, public companies relating to securities issued as well as institutions and professions related to securities."(OJK, 2020b). Applying sharia principles in economic transaction activities and regardless of prohibited things such as usury, gambling, and speculation. The Islamic capital market is different from the ordinary capital market. Some sharia instruments are rolling out in the Indonesian capital market, following Indonesian sharia principles, such as stocks and bonds with specific criteria following sharia principles.

However, the number of investors in the Islamic capital market is lower than the number of investors in the conventional capital market. Currently, 80,000 people invest in the Islamic capital market compared to 2.5 million in the traditional capital market (Hasanah, Hadiantini, \& Kusumawardhani, 2020). This can be the basis that public interest in investing in the Islamic capital market is shallow. One of the causes of the low public interest in investing in the Islamic capital market is the lack of understanding of the Islamic capital market.

A deeper understanding of the capital market is considered very important at this time. Everyone who works or has some funds wants to know where they can invest their money in places with a good value. In other words, an investment should be profitable which means having bright and promising prospects. It is necessary to increase financial literacy, especially among the productive generation who have responsibilities as agents of change. Financial literacy is building from public awareness of the importance of investing and being good at processing the funds they have to provide lasting benefits. 


\section{International Journal of Current Science Research and Review}

ISSN: 2581-8341

\section{Volume 05 Issue 02 February 2022}

DOI: 10.47191/ijesrr/V5-i2-09, Impact Factor: 5.825

The existence of investment galleries throughout Indonesian universities can spur an increase in students' financial literacy. The purpose of establishing a sharia investment gallery on campuses is to increase students understanding of the Islamic capital market and apply it is expected the students can apply their knowledge by becoming investors in the Islamic capital market. With the increasing number of investors in the Islamic capital market, the Islamic capital market in Indonesia will also develop. However, it limited is known how knowledge of the capital market and financial literacy affects people's intention to invest in the Islamic capital market. This study, therefore, used variables of knowledge on capital market and financial literacy to find out the impact on the decision to invest in the Islami capital market.

\section{LITERATURE REVIEW}

\section{A. Sharia Capital Market}

Sharia banking and sharia insurance have grown fastly and it has encouraged market demand for products that can overcome liquidity problems of sharia financial institutions, namely the sharia capital market (Paltrinieri \& Kutan, 2019). The significant potential of the Islamic capital market growing is caused by the high number of industries and potential investors in Indonesia. In addition, the decline in the national economic growth rate after the global crisis in 1998 also affected the capital market sector as a subsystem of the Indonesian national economy. The situation prompted regulators to start developing the application of sharia principles to capital market products as an alternative instrument for capital market activities in Indonesia (Sari, AK, \& Widiyanti, 2018).

Developing a discourse on sharia financial investment through the capital market that applies sharia principles begins with the significant increase in capital accumulation among Muslims domestically and abroad. The countries that first introduced the application of sharia principles in the capital market were Jordan and Pakistan. Since the Pakistani government in 1980 has published The Madarabas Company and Madarabas Ordinance. Meanwhile, in 1978, through Law No. 13/1978, the Jordanian government had allowed Jordan Islamic Bank to issue Muqaradah Bonds. Permission to publish Muqarabah Bond Act in 1981 (Yıldırım, Y1ldirım, \& Diboglu, 2020).

Sharia investment in the financial sector has grown significantly by developing product innovations that are not limited to conventional products such as fixed opinion instruments, derivatives, and mutual fund structures that meet sharia criteria (Al-Salem, 2009). Products that meet sharia criteria have also proven attractive to non-Muslim investors and offer many opportunities even for non-Islamic financial institutions in various parts of the world.

Instruments in the Islamic capital market have differences from conventional capital market instruments. The shares traded on the Islamic capital market must come from issuers that meet sharia criteria. Bonds issued must also use sharia principles, such as mudharabah, musyarakah, ijarah, istishna', salam, and murabahah. In addition to Islamic stocks and bonds, which sells on the Islamic capital market, Islamic mutual funds are mixed investment facilities that combine Islamic stocks and bonds in one product managed by an investment manager. The Islamic capital market is a market in which financial instruments or capital are transacted following sharia and justified.

According to Indonesian Financial Authority Agency regulation number 15/POJK.04/2015, concerning the application of sharia principles in the capital market, states that sharia activities in the capital market are activities related to sharia securities public offering, sharia securities trading, sharia investment management in the capital market. Securities Companies that are partly or wholly based on sharia principles and institutions and professions are associated with Sharia Securities (OJK, 2020b).

Meanwhile, according to the Fatwa of the National Syari'ah Council NO: 40/DSN-MUI/X/2003 concerning the Capital Market and General Guidelines for the Implementation of Sharia Principles in the Capital Market Sector, it is stated that the Capital Market is an activity related to the Public Offering and trading of Securities, Public Companies that relating to the Securities that are issued, as well as institutions and professions related to Securities. Sharia securities are securities, as referred to in the laws and regulations in the capital market sector, are securities whose contracts, company management, and method of issuance comply with Sharia principles (Shofawati, 2018).

Thus, the Islamic capital market is a meeting place for sellers and buyers to conduct transactions to obtain capital. The method of issuance of securities must comply with sharia principles. This is in line with God's commandment contained in Q.S Al Baqarah /2:261

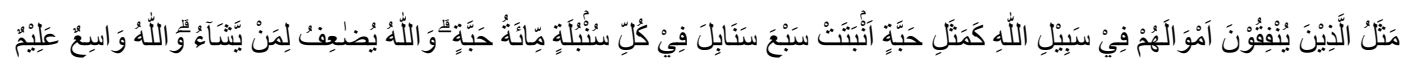




\section{International Journal of Current Science Research and Review}

ISSN: 2581-8341

\section{Volume 05 Issue 02 February 2022}

DOI: 10.47191/ijesrr/V5-i2-09, Impact Factor: 5.825

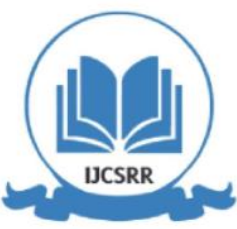

www.ijesrr.org

Translate

"Parable of those who spend their wealth in the way of Allah is like (those who sow) a grain (seed) that grows seven stalks; on each stalk, there are a hundred seeds. Allah multiplies (reward) for whom He wills. Allah is AllEncompassing, All-Knowing."

The interpretation of the verse is the parable of a human doing charity (infaq) in the way of Allah, and the reward will be multiplied by Allah for whom Allah wills. This will be a stimulus for someone to do the infaq. The meaning multiplied to seven hundred does not mean that it is an assigned number, and seven hundred does not indicate above six hundred and ninety-nine or below seven hundred and one. Still, it shows that there are many times that Allah will give to people who do infaq.

In the verse, it is fortunate for people who want to spend their wealth in the way of Allah, implicitly providing information for people who want to invest in accordance with Islamic teaching will get multiple benefits. A financially wealthy person then spends his wealth on the poor through productive efforts which means the person will help the poor for productive purposes. When someone invests his shares in the sharia capital market to spend his wealth solely for the sake of Allah, then it is worth worship, as stated in the interpretation of the verse above. In the Surah An-Nisa, there is also a verse related to investing, the main activity in the Islamic capital market. Allah says in Q.S An-Nisa /4:9

Translate

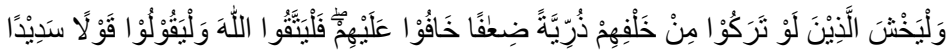

"Should be afraid of those who should leave (die) after them, weak offspring (who) they are worried about. So, fear Allah and speak with the right words (in terms of maintaining the rights of their offspring)."

The interpretation of the verse is intended for people who are around people who have a property and are sick and will die to continue to pay attention to the welfare of their heirs so that there will not be a decline in the future, because often people who are around people who have the property advise the sick person to distribute his wealth to certain people and instead ignore his children in a weak (down) state.

The verse explicitly explains that we are not allowed to leave our families in a slumped or weak state; therefore, humans living in society are encouraged to invest in the long term so that the family economy improves in the future. This investment will be given to the heirs so that their lives will be prosperous.

Investments made by investors in the sharia capital market are a form so that later heirs will also be able to enjoy the results of current and future investments and are expected to continue their investment and develop it so that it is sustainable for the benefit of the offspring.

\section{B. Financial Literacy}

Finance is an important aspect inherent in the life of the wider community. Financial knowledge possessed can determine financial products that can optimize financial decisions (Abreu \& Mendes, 2010). Knowledge of finance becomes essential for individuals so that they are not wrong in making financial decisions later. If they lack financial knowledge, it will result in losses for the individual, both due to inflation and a decline in economic conditions at home and abroad. Financial literacy can be interpreted as knowledge to manage finances. The higher the level of financial literacy that a person has will produce intelligent economic behavior and effective financial management.

The financial services authority defines financial literacy as the level of knowledge, skills, and confidence and its products and services, expressed in parameters or measures of literacy (Remund, 2010). Disclosure of this literacy index is essential in seeing the accurate map regarding the level of public knowledge of the features, benefits and risks, their rights and obligations as users of financial products and services.

Financial literacy consists of several abilities and knowledge about finances that a person has to manage or use a certain amount of money to improve his standard of living and aim to achieve prosperity. Understanding the financial implications of financial decisions is fundamental in financial literacy. An informed decision is recognized as an instrument to achieve the expected outcome. Financial literacy includes several economic dimensions that must be mastered. Several sizes of financial literacy have general knowledge of finance, savings and loans, insurance, and investment. 


\section{International Journal of Current Science Research and Review}

ISSN: 2581-8341

\section{Volume 05 Issue 02 February 2022}

DOI: 10.47191/ijesrr/V5-i2-09, Impact Factor: 5.825

IJCSRR@ 2022

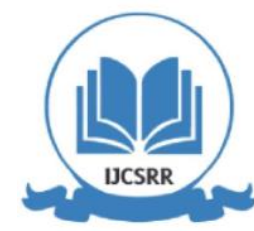

www.ijesrr.org

\section{General knowledge of finance}

Knowledge of finance includes knowledge of personal finance, namely how to manage income and expenses and understand the basic concepts of finance (Peng, Bartholomae, Fox, \& Cravener, 2007). The primary financial ideas include calculating simple interest rates, compound interest, the effect of inflation, opportunity cost, time value of money, liquidity of an asset, and others. Savings and borrowing is a banking product better known as savings and credit (Fletschner \& Kenney, 2014). Savings is an amount of money that is for future needs. Someone with a higher income than his expenses will tend to keep the rest of the capital. The form of savings can be in the form of savings in a bank or in the form of time deposits. While borrowing is a facility to borrow money and repay it within a certain period with interest.

Insurance is a form of financial protection that can be done in life insurance, property insurance, education insurance, and health insurance (Nandi \& Schneider, 2020). The purpose of insurance is to obtain compensation in an unexpected event such as death, loss, accident, or damage. Insurance involves the insured party making regular premium payments within a specific time, which is helpful in exchange for a policy that guarantees the protection obtained from the insured party.

Investment is saving or putting money to work to make more money (Jain \& Joy, 1997). Investment is also a form of commitment to several funds made to get profits in the future (Strine, 2016). The method often used by someone to invest is by putting money into securities, including stocks, bonds, and mutual funds, or owning real estate. The number of investors in the Islamic capital market in October 2020 reached 81,813 investors and is increasing every year (Alam, Duygun, \& Ariss, 2016). However, this number is still far from the number of investors in the Indonesian capital market, which got 3.87 million Single Investor Identification (SID).

Based on the 2019 national financial literacy and financial inclusion index survey results, the lack of investors in the capital market means that the level of public financial literacy is still far behind. The national financial literacy index published by the OJK shows that Indonesia's national financial literacy rate is only 38.03\% (Noor, Fourqoniah, \& Aransyah, 2020). Islamic financial literacy refers to the financial literacy of a consumer of Islamic financial products and services to know and understand Islamic financial service institutions (Antara, Musa, \& Hassan, 2016). As such Muslim community can manage Islamic finance to increase the benefit. The third national financial literacy survey conducted in 2019 by the Indonesian Financial Services Authority showed that the conventional financial literacy index reached 37.72 percent, while the Islamic financial literacy index only reached 8.93 percent in the same year. Comparing the two indices, the total Islamic financial literacy index differs quite a lot from conventional financial literacy, with an increase of 8.2 percent in three years, while the Islamic financial literacy index is only 0.83 percent in three years (OJK, 2020a).

Based on these data, Islamic financial literacy is needed to educate and provide insight to the public on the importance of managing finances according to Islamic law. Literacy in Islam has become a part of the development of Islam and Muslim culture. It recommends that its followers read in a knowledge that begins with ignorance to encourage a literacy culture. In Islam, it promotes a literacy culture in terms of reading and writing. The concept of literacy in Islam has become part of the development of Islam and Muslim culture since the Prophet's time (Kennedy, 2015; Rusli, Hasyim, \& Nurdin, 2021; Rusli \& Nurdin, 2021).

The capital city of Jakarta occupies the highest level of financial literacy index in Indonesia with a total reaching 59.16 percent by province, followed by DIY Yogyakarta with achievement of 58.53 percent and Central Java with a triumph of 47.38 percent. Meanwhile, Central Sulawesi province only reached 39.63\% (OJK, 2020a). Through the Indonesia Stock Exchange, the government launched a program for the Yuk Nabung Saham campaign to increase the number of investors in both the Islamic and conventional capital markets, targeting students. In addition, seminars and education hold through the IDX investment gallery. Until October 2019, there were three investment galleries available in Central Sulawesi, one of them focused on the Islamic capital market, namely the Sharia Investment Gallery at State Institute for Islamic Studies.

\section{METHODOLOGY}

This study uses a quantitative approach with survey techniques (Boose, 1989; Nurdin, Pettalongi, \& Ahsan, 2019). The research object was students from the Department of Islamic Economics and Islamic Banking of State University of Islamic Studies Datokarama Palu, totaling 94 students who were randomly selected. The survey used Likert scale techniques and it was distributed online using Google form. The data was analyzed using descriptive inferential statistics. The inferential statistics used SPS 23 and Microsoft Excel 2010 program (Nurdin, Pettalongi, \& Mangasing, 2019). Descriptive statistics aim to obtain an overview of 


\section{International Journal of Current Science Research and Review}

ISSN: 2581-8341

Volume 05 Issue 02 February 2022

DOI: 10.47191/ijcsrr/V5-i2-09, Impact Factor: 5.825

IJCSRR@ 2022

Www.ijcsrr.org

respondents, while inferential statistics were used for hypothesis testing. Hypothesis and analysis were tested using software, namely SPSS 23. The data obtained were tested with a simple linear regression analysis model to find out the influence of the independent on the dependent variable. 35

\section{RESULTS AND DISCUSSION}

\section{A. Sample Description and Questionnaires}

The sample of this study was randomly selected from two departments within the Faculty of Islamic Economics and Business. The students were from the years 2017 and 2018 or at the time this study was conducted they were in semester fourth and sixth. There were 21 males and 73 female students with a total sample were 94 students. The sample characteristic is presented in the following table 1 .

Table 1. Description of Sample Quantity

\begin{tabular}{|l|l|l|l|l|}
\hline No. & \multicolumn{2}{|l|}{ Gender } & Force \\
\hline 1 & Male & Female & 2017 & 2018 \\
\hline 2 & 21 & 73 & 42 & 52 \\
\hline Total & 94 & 94 & \\
\hline
\end{tabular}

The students were assigned online questionnaires using Google Forms. All of the questionnaires were completely filled out and returned to us. The results average and median calculation of the questionnaires are presented in the following table 2 .

Table 2. Scale Measurement

\begin{tabular}{|l|l|l|l|l|}
\hline Indicators & Average & Median & Minimum & Maximum \\
\hline X1.1 & 3.891 & 4.000 & 1.000 & 5.000 \\
\hline X1.2 & 4.022 & 4.000 & 1.000 & 5.000 \\
\hline X1.3 & 4.413 & 5.000 & 1.000 & 5.000 \\
\hline X1.4 & 4.022 & 4.000 & 1.000 & 5.000 \\
\hline X1.5 & 3.761 & 4.000 & 1.000 & 5.000 \\
\hline X1.6 & 4.272 & 5.000 & 1.000 & 5.000 \\
\hline X2.1 & 4.120 & 4.000 & 1.000 & 5.000 \\
\hline X2.2 & 3.891 & 4.000 & 1.000 & 5.000 \\
\hline X2.3 & 3.815 & 4.000 & 1.000 & 5.000 \\
\hline X2.4 & 3.891 & 4.000 & 1.000 & 5.000 \\
\hline X2.5 & 4.076 & 4.000 & 1.000 & 5.000 \\
\hline Y1 & 4.326 & 5.000 & 1.000 & 5.000 \\
\hline Y2 & 4.304 & 5.000 & 1.000 & 5.000 \\
\hline Y3 & 4.043 & 4.000 & 1.000 & 5.000 \\
\hline Y4 & 4.196 & 4.000 & 1.000 & 5.000 \\
\hline Y5 & 3.837 & 4.000 & 1.000 & 5.000 \\
\hline
\end{tabular}

The measurement of the scale of the sample on the Financial Literacy variable (X1) for indicators 1 to 5 showed a maximum scale of 5 , a median of 4 , and a minimum of 1 , while the X1.6 had a difference in the median portion obtained, namely 5 , the average for the indicator 2,3,4 and 6 are 4, the standard for indicators of 1 and 5 is 3. Variable Knowledge of investment galleries (X2) showed a maximum scale of 5, median four and minimum, an average of 3 for indicators 2 to 4 , and an average of 4 for indicators 1 and 5 . The variable interest in Investing (Y) respondents gave statements with a maximum scale of 5 medians four except for indicators 1 and 2. Minimum 1 for each indicator, the average for each indicator is four, except for indicator five the average obtained is 3 


\section{International Journal of Current Science Research and Review}

ISSN: 2581-8341

Volume 05 Issue 02 February 2022

DOI: 10.47191/ijesrr/V5-i2-09, Impact Factor: 5.825

IJCSRR@ 2022

WwW.ijcsrr.org

\section{B. Evaluation of Measurement Model \\ Validity test}

The validity test of all indicators for two variables $\mathrm{X}$ and one variable $\mathrm{Y}$ is presented in the following table 3 . The results of the validity test reflect the Financial Literacy, Knowledge of the Capital Market, and Intention to invest in the Islamic capital market.

Table 3. Factor Loading

\begin{tabular}{|l|l|l|l|}
\hline & X1 (Financial Literacy) & X2 (Knowledge of Capital Market) & Y (Intention to Invest) \\
\hline X1.1 & 0,750 & & \\
\hline X1.2 & 0,762 & & \\
\hline X1.3 & 0,892 & & \\
\hline X1.4 & 0,838 & & \\
\hline X1.5 & 0,702 & & \\
\hline X1.6 & 0,811 & & \\
\hline X2.1 & & 0,876 & \\
\hline X2.2 & & 0,792 & \\
\hline X2.3 & & 0,851 & \\
\hline X2.4 & & 0,851 & \\
\hline X2.5 & & 0,847 & \\
\hline Y1 & & & 0,873 \\
\hline Y2 & & & 0,859 \\
\hline Y3 & & & 0,899 \\
\hline Y4 & & & 0,858 \\
\hline Y5 & & & 0,859 \\
\hline Y6 & & & \\
\hline
\end{tabular}

The value generated from each indicator to measure the variable showed that the acceptable deal is 0.7 . The first Financial Literacy indicator is worth 0.750 . The second Financial Literacy indicator is worth 0.762 . The third Financial Literacy indicator is 0.892 . The fourth Financial Literacy indicator is 0.838 . The fifth Financial Literacy indicator is worth 0.702 . The sixth indicator value of the financial literacy indicator is 0.811 . All of the perception indicators show a number $>0.7$, which means that all indicators have passed the test. The first Knowledge on Capital Market indicator shows a value of 0.876 . The second indicator of knowledge on the capital market is worth 0.792 . The third Capital market knowledge indicator is 0.851 . The fourth Capital market knowledge indicator is 0.851 , and the fifth Capital market Knowledge indicator value is 0.847 . All indicators Knowledge about the market capital shows a number 0.7 , which means all indicators are declared to have passed the test. The first investment interest indicator shows a value of 0.873 ; the second investment interest indicator is worth 0.859 ; the third investment interest indicator is 0.899 , the fourth investment interest indicator is 0.858 , the fifth investment interest indicator is 0.769 , and the sixth investment interest indicator is 0.859 , which means that all indicators have passed the test.

Table 4. Average Variance Extracted (AVE)

\begin{tabular}{|l|l|}
\hline Variables & Average extracted variants (AEV) \\
\hline Financial literacy (X1) & 0,632 \\
\hline Knowledge of stock market (X2) & 0,712 \\
\hline Intention to Invest (Y) & 0,729 \\
\hline
\end{tabular}




\section{International Journal of Current Science Research and Review}

ISSN: 2581-8341

\section{Volume 05 Issue 02 February 2022}

DOI: 10.47191/ijcsrr/V5-i2-09, Impact Factor: 5.825

IJCSRR@ 2022

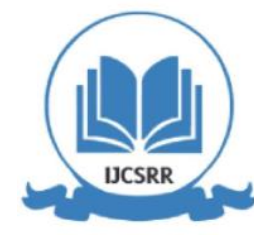

$\underline{\text { www.ijcsrr.org }}$

The value that each variable owns for a variable that is declared valid is 0.5 . The financial literacy test results showed a value of $0.632>0.5$, while knowledge of the capital market was worth $0.712>0.5$, and the importance of investment interest was $0.729>$ 0.5 . All variables show results $>0.5$. Then the test results are declared valid.

Table 5. Fornell Larcker Criterion or HTMT

\begin{tabular}{|l|l|l|l|}
\hline Variables & $\begin{array}{l}\text { Financial literacy } \\
(\mathrm{X} 1)\end{array}$ & $\begin{array}{l}\text { Knowledge of stock } \\
\text { market (X2) }\end{array}$ & Intention to invest (Y) \\
\hline $\mathrm{X} 1$ & 0,795 & & \\
\hline $\mathrm{X} 2$ & 0,654 & 0,844 & 0,877 \\
\hline $\mathrm{Y}$ & 0,754 & 0,782 & \\
\hline
\end{tabular}

Fornell Larcker Criterion is the correlation value between variables. For its measurement, the correlation value between variables and the variables themselves must be greater than the correlation values of other variables. The Fornell Larcker Criterion table shows the value between financial Literacy variables, which is 0.795 greater than the correlation value with different variables, the value of the Knowledge about the capital market variable is 0.844 which is more significant than the correlation value between other variables, the value of the investment interest variable is 0.877 greater than the value of correlation between other variables which means passing the test.

Table 6. Cross Loading

\begin{tabular}{|l|l|l|l|}
\hline Variabel & X1 (Financial literacy & X2 (knowledge on capital market) & Y (Intention to invest) \\
\hline X1.1 & 0,750 & 0,529 & 0,672 \\
\hline X1.2 & 0,762 & 0,409 & 0,638 \\
\hline X1.3 & 0,892 & 0,595 & 0,814 \\
\hline X1.4 & 0,838 & 0,575 & 0,712 \\
\hline X1.5 & 0,702 & 0,441 & 0,573 \\
\hline X1.6 & 0,811 & 0,546 & 0,745 \\
\hline X2.1 & 0,538 & 0,876 & 0,676 \\
\hline X2.2 & 0,608 & 0,792 & 0,679 \\
\hline X2.3 & 0,470 & 0,851 & 0,560 \\
\hline X2.4 & 0,490 & 0,851 & 0,591 \\
\hline X2.5 & 0,618 & 0,847 & 0,755 \\
\hline Y1 & 0,851 & 0,669 & 0,873 \\
\hline Y2 & 0,822 & 0,622 & 0,859 \\
\hline Y3 & 0,757 & 0,744 & 0,899 \\
\hline Y4 & 0,701 & 0,606 & 0,858 \\
\hline Y5 & 0,609 & 0,718 & 0,769 \\
\hline Y6 & 0,728 & 0,652 & 0,859 \\
\hline
\end{tabular}

The correlation value between indicators and variables, for measurement the value between indicators and the variables themselves must be greater than the values between indicators to other variables. The test results show that the values between indicators and the variables themselves are more significant than those between indicators to other variables. Meanwhile, the reliability test of the three variables showed the following results as depicted in table 7 and table 8 below. 


\section{International Journal of Current Science Research and Review}

ISSN: 2581-8341

Volume 05 Issue 02 February 2022

DOI: 10.47191/ijesrr/V5-i2-09, Impact Factor: 5.825

IJCSRR@ 2022

Table 7. Component Reliability

\begin{tabular}{|l|l|}
\hline Variable & Reliability Komposit \\
\hline Financial Literacy (X1) & 0,911 \\
\hline Knowledge on capital market (X2) & 0,925 \\
\hline Intention to Invest (Y) & 0,942 \\
\hline
\end{tabular}

Table 8. Cronbach's Alpha

\begin{tabular}{|l|l|}
\hline Variable & Cronbach's Alpha \\
\hline Financial literacy (X1) & 0,882 \\
\hline Knowledge of Capital market (X2) & 0,899 \\
\hline Interest in investing (Y) & 0,925 \\
\hline
\end{tabular}

To test the reliability of the measurement through the Composait Reliability and Cronbach's Alpha must value $>0.7$. The results show that the Composite Reliability financial literacy value is 0.911 and Cronbach's Alpha is worth 0.882. For the knowledge capital market's variable showed that the Composite Reliability is worth 0.925 Cronbach's Alpha 0.899, and Composait Reliability variable interest in investing is 0.942 Cronbach's Alpha 0.925 the three variables show a value of $>0.7$ which means that they pass the test.

\section{Evaluation of Structural Model}

\section{Hypothesis testing}

To test the hypothesis, we looked at the R-Square value, which shows how much the exogenous/independent variable, namely Financial Literacy (X1) and Knowledge of the Capital Market (X2). Affect the dependent variable, namely Investment Interest ( Y). Then to find out whether the exogenous variable has a positive or negative effect, we see the Path Coefficient value. After that, to find out $\mathrm{H} 1$ and $\mathrm{H} 2$ whether the exogenous variable has a partially significant impact, it can be seen on the T-Statistic value. Meanwhile to find out $\mathrm{H} 3$ whether the exogenous variable simultaneously has a substantial effect on endogenous variables can be seen from the results of the comparison of the $\mathrm{F}$ table and calculated $\mathrm{F}$ test.

Table 9. R-Square

\begin{tabular}{|l|l|}
\hline Variable & R Square \\
\hline Interest in investing (Y) & 0,845 \\
\hline
\end{tabular}

The R-Square value is $0.845 \times 100=84.5 \%$. The endogenous variable, namely interest in investing (Y) of $84.5 \%$, is influenced by exogenous/independent variables, namely financial literacy (X1) and knowledge of the capital market (X2). In comparison, the remaining $15.5 \%$ is influenced by other factors not examined in this study.

Table 10. Path coefficient

\begin{tabular}{|l|l|}
\hline Variable & Interest in investing (Y) \\
\hline Financial Literacy (X1) & 0,638 \\
\hline Knowledge of Investment Gallery (X2) & 0,365 \\
\hline
\end{tabular}

For the measurement of Path Coefficient $>0$, it will be positive. The value of each exogenous/independent variable Financial literacy (X1) shows $0.638>0$. Then, the financial literacy variable positively affects the investment interest variable. At the same time, knowledge of the capital market (X2) shows a value of $0.3365>0$ which means that knowledge of the capital market positively affects investment interest.

Table 11. T-Statistic

\begin{tabular}{|l|l|}
\hline Variables & T Statistics $(|\mathrm{O} / \mathrm{STDEV}|)$ \\
\hline $\mathrm{X} 1(\mathrm{LK})->\mathrm{Y}(\mathrm{MB})$ & 10,000 \\
\hline $\mathrm{X} 2(\mathrm{PGI})->\mathrm{Y}(\mathrm{MB})$ & 5,750 \\
\hline
\end{tabular}




\section{International Journal of Current Science Research and Review}

ISSN: 2581-8341

\section{Volume 05 Issue 02 February 2022}

DOI: 10.47191/ijesrr/V5-i2-09, Impact Factor: 5.825

IJCSRR@ 2022

For significance analysis with an error rate of 5\% with a T-statistical value $>1.96$ and the independent variable. The financial literacy variable (X1) shows a value of $10,000>1.96$, which means $\mathrm{H} 0$ is rejected, but $\mathrm{H} 1$ is accepted. The variable knowledge of the capital market (X2) offers a value of $5.750>1.96$, which means $\mathrm{H} 0$ is rejected, and $\mathrm{H} 2$ is accepted, so it can be concluded that financial literacy and knowledge of the capital market partially have a positive and significant effect on the investment interest variable.

F test

Test Simultaneously or together, to test the truth of H3; the F test is used with a significance level of $5 \%(a=0.05)$ with the calculated $\mathrm{F}$ test formula.

$$
F=\frac{\mathrm{R}^{2} / \mathrm{k}}{1-\mathrm{R}^{2} /(\mathrm{n}-\mathrm{k}-1)}
$$

Description : :

$\mathrm{R}^{2}=$ Coefficient of determination

$\mathrm{k}=$ Number of exogenous/independent variables

$\mathrm{n}=$ Number of samples

$$
F=\frac{0,845 / 2}{1-0,845 /(89-2-1)}=\frac{0,4225}{0,155 / 86}=\frac{0,4225}{0,002}=211,25
$$

To determine the critical value (F-Table), with degrees of freedom (df), the numerator (df1) is k, and (df2) for the denominator is $\mathrm{n}-\mathrm{k}-1$ with a significance level $(\alpha=5 \%)$. Where $\mathrm{k}$ is the number of independent variables and $\mathrm{n}$ is the number of samples. If the calculation results show Fcount $<$ Ftable, then $\mathrm{H} 0$ is accepted, $\mathrm{H} 3$ is rejected, and vice versa.

The value of F-table with a significance of $=5 \% \mathrm{df} 1=2$ and df $2=(89-2-1)=86$ is 3.10 . The value of the F-count on the independent variable is $211.25>$ F-table of 3.10, which means H3 is accepted and H0 is rejected. The financial literacy variable and knowledge of the capital market have a significant effect on the investment interest variable.

\section{Discussion}

By looking at the results of the tests that have been carried out, it can be seen that the variables of financial literacy and knowledge of the capital market have a positive and partially significant effect on students' interest in investing in the Islamic capital market, where the results of this study is consistent with previous studies (e.g: Raut, 2020). This can be seen through the path coefficient value, where the financial literacy variable (X1) shows a positive value of 0.638 with a T-statistic value of 10,000 . In contrast, the knowledge about the capital market variable (X2) shows a path coefficient value of 0.365 with a T-statistic value of 5.750. From the study results, it can be seen that the variable that dominates in influencing student interest in investing in the Islamic capital market is financial literacy.

The results of the F test indicate that the variable financial literacy and knowledge of the capital market simultaneously affect student interest in investing in the Islamic capital market with the F-count value on the independent variable of 211.25 > F-table of 3.10. This is supported by the R-Square test of $84.5 \%$ of students' interest in investing is influenced by independent variables, namely financial literacy (X1) and knowledge of the capital market (X2). In comparison, the remaining $15.5 \%$ is influenced by other factors not examined in this study.

The need to provide education about finance and investment to students can be obtained through lectures. However, apart from going through classes, students must also find their sources of education about finance and investment to improve the quality and quantity of their financial literacy. One source of education or financial literacy is the capital market, which has spread to almost all campuses in Indonesia. It is hoped that a sharia investment gallery located at the Islamic economics and business faculty of State University of Islamic Studies Datokarama Palu can increase student interest in investing in the Islamic capital market.

\section{E. Financial Literacy on Investment Interest}

By looking at the results of this study, it was found that the higher the financial literacy of students, the higher their interest in investing in the Islamic capital market. In this study, it was also found that the level of financial literacy possessed by students of the Islamic economics and business faculty is very high. This is because the Islamic economics and business faculty students have 


\section{International Journal of Current Science Research and Review}

ISSN: 2581-8341

\section{Volume 05 Issue 02 February 2022}

DOI: 10.47191/ijcsrr/V5-i2-09, Impact Factor: 5.825

IJCSRR@ 2022

www.ijcsrr.org

obtained sufficient Islamic financial literacy through the courses taken, especially the market course. Islamic capital and Islamic financial institutions in the sixth semester. The level of Islamic financial literacy of students from the faculty of Islamic economics and business is high. Seeing the respondent data that all students know that the Islamic capital market exists for people who want to invest following Islamic principles, namely avoiding usury as explained by Allah in His word QS. Ali'Imran /3:130 which reads:

Translate

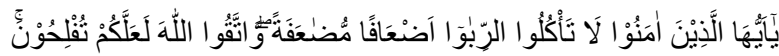

O you who believe, do not eat double usury and fear Allah so that you may be successful.

The interpretation of the verse above explains withdrawing a loan that is obligated to remove the principal without charging interest, let alone increasing it every year. This is not justified in Islam because Islam essentially guarantees profit and success by avoiding usury (Marzuki \& Nurdin, 2020; Musyahidah, Ermawati, \& Nurdin, 2021).

Financial literacy, especially Islamic financial literacy, increases students' understanding of choosing and managing finances according to Islamic law. Their financial literacy affects their interest in investing in the Islamic capital market because they want to manage their finances following Islamic law (Nurdin \& Yusuf, 2020). The interest is shared by all students at the faculty of Islamic economics and business because they understand that financial literacy must be mastered before investing. They appreciate that Islamic capital market products can be purchased as needed, such as sharia shares, Sukuk, or sharia mutual funds. They are looking to know the advantages and disadvantages of the type of Islamic investment to be taken.

\section{F. Knowledge of the capital market to investment interest}

By looking at the results of this study, it can be seen that the more positive or more knowledge about the capital market, the higher their interest in investing in the Islamic capital market (Ermawati, Musyahidah, \& Nurdin, 2021). The ability in question is that they know a sharia investment gallery in the Islamic economics and business faculty. Participate in activities both studies and seminars held by the Sharia Capital Market Study Group as the manager of the investment gallery and wish to invest in the sharia capital market through the sharia investment gallery.

Having more profound knowledge in a field can make a person more careful in making decisions to avoid losses that will occur themselves. Allah has explained this in His word Q.S Al - Baqarah /2: 269

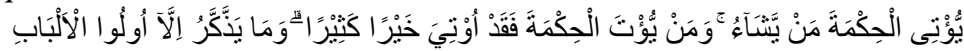

Translate

He (Allah) grants wisdom to whom He will. Indeed, whoever is given knowledge has been awarded a lot of goodness. No one can take lessons (from him), except ululalbab.

\section{CONCLUSION}

Based on the research results above, it can be concluded that financial literacy variables and knowledge of the capital market have a positive and significant effect, partially or simultaneously, on students' interest in the Islamic capital market. The financial literacy variable is more dominant compared to the knowledge variable about the capital market. Financial literacy is more accessible to obtain than knowledge about sharia investment galleries. Our study highlighted an important point is that attracting a new generation in the Islamic capital market requires more attention from government and education institutions to provide them with sufficient knowledge and literacy of capital market and financial. Future studies need to study a better way to provide the young generation with financial literacy and capital market knowledge.

\section{REFERENCES}

1. Osinubi, T.S. and L.A. Amaghionyeodiwe, Stock Market Development and Long-Run Growth in Nigeria. Journal of African Business, 2003. 4(3): p. 103-129.

2. Wahyudi, I. and G.A. Sani, Interdependence between Islamic capital market and money market: Evidence from Indonesia. Borsa Istanbul Review, 2014. 14(1): p. 32-47. 


\section{International Journal of Current Science Research and Review}

ISSN: 2581-8341

Volume 05 Issue 02 February 2022

DOI: 10.47191/ijesrr/V5-i2-09, Impact Factor: 5.825

IJCSRR@ 2022

www.ijesrr.org

3. Wahyuni, S.N. and Y.P. Astuti. The Influence of Demographic Factors on Investment Decisions in Indonesia in the Pandemic Time Covid-19. in The 3rd International Conference of Banking, Accounting, Management and Economics (ICOBAME 2020). 2021. Jakarta: Atlantis Press.

4. OJK, Undang-undang Nomor 8 Tahun 1995 tentang Pasar Modal. 2020, Agency of Indonesian Financial Authority: Jakarta.

5. Hasanah, S.F.N., R. Hadiantini, and A.P. Kusumawardhani. Analysis of Macroeconomic Factors and Fundamental Factors to Sharia Stock Return on Trade, Services and Investment Sector Companies in Jakarta Islamic Index (JII) Period 2014 2018. in Proceedings of the First International Conference on Science, Technology, Engineering and Industrial Revolution (ICSTEIR 2020). 2020. Atlantis.

6. Paltrinieri, A. and A. Kutan, Islamic finance and business: an overview with directions for further research. International Journal of Emerging Markets, 2019. 14(4): p. 497-502.

7. Sari, N., S. AK, and M. Widiyanti, The Impact of Islamic Capital Market Development on Economic Growth: The Case of Indonesia Journal of Smart Economic Growth, 2018. 3(2): p. 21-30.

8. Yıldırım, S., D.C. Yıldırım, and P. Diboglu, Does Sukuk market development promote economic growth? PSU Research Review, 2020. 4(3): p. 209-218.

9. Al-Salem, F.H., Islamic financial product innovation. International Journal of Islamic and Middle Eastern Finance and Management, 2009. 2(3): p. 187-200.

10. Shofawati, A. Islamic Screening Mechanism of Islamic Capital Market-A Comparison Between the Fatwa-DSN-MUI, the Kuala Lumpur Stock Exchange Islamic Index and the Dow Jones Islamic Market Index. in The 2018 International Conference of Organizational Innovation. 2018. Jakarta: KnE Social Science.

11. Abreu, M. and V. Mendes, Financial literacy and portfolio diversification. Quantitative Finance, 2010. 10(5): p. $515-528$.

12. Remund, D.L., Financial Literacy Explicated: The Case for a Clearer Definition in an Increasingly Complex Economy. Journal of Consumer Affairs, 2010. 44(2): p. 276-295.

13. Peng, T.-C.M., et al., The Impact of Personal Finance Education Delivered in High School and College Courses. Journal of Family and Economic Issues, 2007. 28(2): p. 265-284.

14. Fletschner, D. and L. Kenney, Rural Women's Access to Financial Services: Credit, Savings, and Insurance, in Gender in Agriculture: Closing the Knowledge Gap, A.R. Quisumbing, et al., Editors. 2014, Springer Netherlands: Dordrecht. p. $187-$ 208.

15. Nandi, S. and H. Schneider, When state-funded health insurance schemes fail to provide financial protection: An in-depth exploration of the experiences of patients from urban slums of Chhattisgarh, India. Global Public Health, 2020. 15(2): p. 220-235.

16. Jain, A.K. and A. Joy, Money matters: An exploratory study of the socio-cultural context of consumption, saving, and investment patterns. Journal of Economic Psychology, 1997. 18(6): p. 649-675.

17. Strine, L.E., Securing Our Nation's Economic Future A Sensible, Nonpartisan Agenda to Increase Long-Term Investment and Job Creation in the United States. The Business Lawyer, 2016. 71(4): p. 1081-1112.

18. Alam, N., M. Duygun, and R.T. Ariss, Green Sukuk: An Innovation in Islamic Capital Markets, in Energy and Finance: Sustainability in the Energy Industry, A. Dorsman, Ö. Arslan-Ayaydin, and M.B. Karan, Editors. 2016, Springer International Publishing: Cham. p. 167-185.

19. Noor, M., F. Fourqoniah, and M.F. Aransyah, The Investigation of financial inclusions, financial literation, and financial technology in Indonesia Journal of Perspectives on Financing and Regional Development 2020. 8(3): p. 257-268.

20. Antara, P.M., R. Musa, and F. Hassan, Bridging Islamic Financial Literacy and Halal Literacy: The Way Forward in Halal Ecosystem. Procedia Economics and Finance, 2016. 37: p. 196-202.

21. OJK, Survei Nasional Literasi dan Inklusi Keuangan 2019. 2020, Indonesian Financial Authority: Jakarta.

22. Kennedy, H., The Prophet and the Age of the Caliphates : The Islamic Near East from the Sixth to the Eleventh Century. 2015, London: Routledge.

23. Rusli, R., M.S. Hasyim, and N. Nurdin, A New Islamic Knowledge Production And Fatwa Rulings: How Indonesia's Young Muslim Scholars Interact With Online Sources. Journal of Indonesian Islam, 2021. 14(2): p. 499-518. 


\section{International Journal of Current Science Research and Review}

ISSN: 2581-8341

Volume 05 Issue 02 February 2022

DOI: 10.47191/ijesrr/V5-i2-09, Impact Factor: 5.825

IJCSRR@ 2022

www.ijcsrr.org

24. Rusli, R. and N. Nurdin, Understanding Indonesia millennia Ulama online knowledge acquisition and use in daily fatwa making habits. Education and Information Technologies, 2021.

25. Boose, J.H., A survey of knowledge acquisition techniques and tools. Knowledge Acquisition, 1989. 1(1): p. 3-37.

26. Nurdin, N., S.S. Pettalongi, and M.N. Ahsan. Implementation of Teaching Quality Assessment System Using Android. in 2019 5th International Conference on Science and Technology (ICST). 2019.

27. Nurdin, N., S.S. Pettalongi, and M. Mangasing. Understanding Digital Skill Use from The Technology Continuance Theory (TCT). in 2019 6th International Conference on Information Technology, Computer and Electrical Engineering (ICITACEE). 2019.

28. Raut, R.K., Past behaviour, financial literacy and investment decision-making process of individual investors. International Journal of Emerging Markets, 2020. 15(6): p. 1243-1263.

29. Marzuki, M. and N. Nurdin, The Influence of Halal Product Expectation, Social Environment, and Fiqih Knowledge on Intention to Use Shariah Financial Technology Products. International Journal of Innovation, Creativity and Change, 2020. 13(1): p. 171-193.

30. Musyahidah, S., E. Ermawati, and N. Nurdin, The Effect of Riba Avoidance and Product Knowledge on the Decision to Become a Customer of Islamic Banks. International Journal of Multidisciplinary Research and Analysis, 2021. 4(8): p. 1090-1101.

31. Nurdin, N. and K. Yusuf, Knowledge management lifecycle in Islamic bank: the case of syariah banks in Indonesia. International Journal of Knowledge Management Studies, 2020. 11(1): p. 59-80.

32. Ermawati, E., S. Musyahidah, and N. Nurdin, Muslim Society Perspective on Islamic Banking Corporate Social Responsibility in Indonesia (Based On Qur'an and Hadits Economic Themes). International Journal of Business and Management Review, 2021. 9(3): p. 29-40.

Cite this Article: Malkan Malkan, Hilal Malarangan, Nurdin Nurdin (2022). The Effect of Financial Literacy and Knowledge of Capital Market on Intention to Invest on Islamic Stock Exchange. International Journal of Current Science Research and Review, 5(2), 363-374 